\title{
Screening of Marketed Pork for Ceftiofur residues by HPLC And UV-Vis Spectrophotometer
}

\author{
D.C. Roy ${ }^{1}$, R. Gogoi ${ }^{2}$ and M. Gogoi ${ }^{3}$ \\ ${ }^{1}$ Professor, Department of Pharmacology \& Toxicology, C.V.Sc, AAU, Khanapara, Assam, India \\ ${ }^{2}$ PhD Scholar, Department of Pharmacology \& Toxicology, C.V.Sc, AAU, Khanapara, Assam, India \\ ${ }^{3}$ MVSc, Department of Pharmacology \& Toxicology, C.V.Sc, AAU, Khanapara, Assam, India
}

\begin{abstract}
In the present study pork samples from markets of Assam, India were collected and analyzed to detect the presence of Ceftiofur residues using a High Performance liquid Chromatography (HPLC) System and a UV-Vis Spectrophotometer. 300 nos. of representative pork samples were collected from different pork markets of Assam. The samples after collection were preserved at $-20^{\circ} \mathrm{C}$. Analyses of the samples using High Performance Liquid Chromatography with UV-Vis Detector were done as per the method of Oka et al, 1985 while analyses of the same samples using UV-Vis Spectrophotometer were done as per the method of Annapurna et al. ,2009. Ceftiofur residues were extracted with Mc-IIvaine buffer. Solid phase extraction clean up was done with Sep-pak $C_{18}$ cartridge. Recovery ranged from 83-95\% (HPLC) and 5780\%(Spectrophotometer).Out of the tested samples, 10 nos of the screened samples were detected to be positive for trace residues of Ceftiofur using Spectrophotometer while 14 nos of same samples were detected for ceftiofur residue using HPLC method which were well below the MRL value.
\end{abstract}

Keywords: Assam, Ceftiofur, High Performance Liquid Chromatography, Pork, Solid Phase Extraction, Spectrophotometer

\section{Introduction}

Ceftiofur, a third-generation cephalosporin is a broad spectrum antibacterial agent used for the treatment of digestive and respiratory diseases in livestock [1][2]. Residues of Ceftiofur are reported to be found in animal tissues and milk and their undesirable levels may lead to many health hazards in human [3][4]. For these reasons, the control of ceftiofur residues in edible animal tissues is mandatory. To protect the health of consumers, many countries have established Maximum Residue Limits (MRLs) for different antibiotics including Ceftiofur in food-producing animals. The MRLs of Ceftiofur in swine tissues established by European Union (EU) are $0.5 \mu \mathrm{g} \mathrm{g}^{-1}$ in muscle, $3.0 \mu \mathrm{g} \mathrm{g}^{-1}$ in liver, and $4.0 \mu \mathrm{g} \mathrm{g}^{-1}$ in kidney. Pork is regarded as an important meat in Assam including N.E. States which comprises of about 39\% of total meat share in Assam [5]. The present study was undertaken to detect the presence of Ceftiofur residues in marketed pork of Assam by using both Spectrophotometric and HPLC method

\section{Materials And Methods}

300 nos. of representative pork samples were collected from different pork markets of Assam as listed in TABLE 1. Representative tissue samples of muscle, kidney and liver weighing $30 \mathrm{~g}$ each belonging to same carcass were wrapped in polythene bags and transported in thermo-cooled containers jacketed with ice. The samples were stored at $-20^{\circ} \mathrm{C}$ till the time of processing. The samples after collection were preserved at $-20^{\circ} \mathrm{C}$.

$10 \mathrm{~g}$ of each sample was taken in a blender and to it added $10 \mathrm{ml}$ of distilled water and then blended. 5 $\mathrm{ml}$ of the mixture was taken and to it added equal volume of $0.1 \mathrm{M} \mathrm{Na}_{2}$ EDTA - McIIvaine buffer ( $\mathrm{pH} 4.0$ ) and kept for 10 minutes. The mixture was sonicated and left undisturbed for 15 minutes. The mixture was then centrifuged at $0^{\circ} \mathrm{C}$ at $10,000 \mathrm{rpm}$ for 30 minutes. The collected supernatant was then filtered using Whatman No.42. Solid phase extraction clean up was done with Sep-Pak $\mathrm{C}_{18}$ cartridge. The filtrate was passed through C18 polymeric cartridge, after which it was micro filtered using $0.22 \mu$ filter paper and the filtrate was ready for analysis.

Ceftiofur residues in pork were estimated by using a High Performance liquid Chromatography System (Waters HPLC) and a UV-Vis Spectrophotometer (Systronics). Analyses of the samples using High Performance Liquid Chromatography with UV-Vis Detector were done as per the method of Oka et al, 1985 [6] while analysis of the same samples using UV-Vis Spectrophotometer were done as per the method of Annapurna et al.2009[7]. 
Screening of Marketed Pork for Ceftiofur residues by HPLC and UV-Vis Spectrophotometer

Table 1: Pork samples collected from different market places of Assam

\begin{tabular}{|c|c|c|c|c|}
\hline Place & Kidney & Liver & Muscle & Total \\
\hline Guwahati & 16 & 18 & 16 & 50 \\
\hline Jorhat & 12 & 12 & 12 & 36 \\
\hline Nalbari & 15 & 17 & 15 & 47 \\
\hline Tezpur & 12 & 12 & 12 & 36 \\
\hline Nagoan & 15 & 18 & 18 & 51 \\
\hline Goalpara & 15 & 11 & 12 & 38 \\
\hline Morigoan & 15 & 12 & 15 & 42 \\
\hline TOTAL & $\mathbf{1 0 0}$ & $\mathbf{1 0 0}$ & $\mathbf{1 0 0}$ & $\mathbf{3 0 0}$ \\
\hline
\end{tabular}

III. Results And Discussion

Over all, 7 number of zones within the state of Assam have been developed and all total 300 number of samples i.e., 100 numbers of sample each of muscle, liver and kidney were collected.

Out of 300 numbers of total samples, only 10 numbers of samples showed detectable ceftiofur residues using Spectrophotometer (4 kidney, 3 liver and 3 muscle samples). $8.33 \%$ of the sample collected from Jorhat were detected to be positive for trace residues of ceftiofur while only 1 sample each from Tezpur, Goalpara and Morigaon was found to be positive for ceftiofur residue as listed in TABLE 2. Not a single sample of pork tissues were found to be above the MRL value.

As listed in TABLE 3, only 14 numbers of samples showed detectable ceftiofur residues using HPLC (5 kidney, 3 liver and 6 muscle samples). All the samples were below the permissible limit.

The detectable levels in kidney were found to be highest as compared to muscle and liver samples. This finding can be correlated with the study of ceftiofur done by Beconi-Berker et al (1996) [8] where concentrations were found to be highest in kidney. But in contrast with Payne et al (loc cited) who reported higher concentration of ceftiofur in liver of cattle, level of residues in liver in the present study were lower than the kidney samples . Residue level of ceftiofur detected using HPLC in muscle, kidney and liver were 0.015$0.410 \mu \mathrm{g} \mathrm{g}^{-1}, 0.020-2.540 \mu \mathrm{g} \mathrm{g}^{-1}$ and $0.018-2.229 \mu \mathrm{g} \mathrm{g}^{-1}$ respectively whereas residue level of Ceftiofur using Spectrophotometer were $0.085-0.450 \mu \mathrm{g} \mathrm{g}^{-1}, 1.380-3.120 \mu \mathrm{g} \mathrm{g}^{-1}, 1.570-2.350 \mu \mathrm{g} \mathrm{g}^{-1}$ respectively in muscle, kidney and liver samples as listed in TABLE 4.

Recovery ranged from $83-95 \%$ for HPLC and $57-80 \%$ for Spectrophotometer. Limit of Detection (LOD) was $0.015 \mu \mathrm{g} \mathrm{g}^{-1}$ for HPLC and $0.085 \mu \mathrm{g} \mathrm{g}^{-1}$ for Spectrophotometer .

Table 2: Tabular representation of location wise distribution of Ceftiofur residues using Spectrophotometer.

\begin{tabular}{|c|c|c|c|c|c|}
\hline $\begin{array}{l}\text { Sl. } \\
\text { No. }\end{array}$ & Locations & $\begin{array}{c}\text { Samples } \\
\text { Screened }\end{array}$ & Residues Detected & $\begin{array}{c}\text { Detected percentage } \\
(\boldsymbol{\%})\end{array}$ & $\begin{array}{c}\text { Residue above } \\
\text { MRL }\end{array}$ \\
\hline 1 & Guwahati & 50 & $4(\mathrm{~K}-2, \mathrm{~L}-2, \mathrm{M}-0)$ & 8.00 & ND \\
\hline 2 & Jorhat & 36 & $2(\mathrm{~K}-0, \mathrm{~L}-1, \mathrm{M}-1)$ & 5.56 & ND \\
\hline 3 & Nalbari & 47 & ND & 0.00 & ND \\
\hline 4 & Tezpur & 36 & $2(\mathrm{~K}-1, \mathrm{~L}-0, \mathrm{M}-1)$ & 5.56 & ND \\
\hline 5 & Nagoan & 51 & ND & 0.00 & ND \\
\hline 6 & Goalpara & 38 & $2(\mathrm{~K}-1, \mathrm{~L}-0, \mathrm{M}-1)$ & 5.26 & ND \\
\hline 7 & Morigoan & 42 & ND & 0.00 & ND \\
\hline & TOTAL & $\mathbf{3 0 0}$ & $\mathbf{1 0}(\mathbf{K}-\mathbf{4 , L - 3 , M - 3})$ & $\mathbf{3 . 3 3}$ & ND \\
\hline
\end{tabular}

ND- Not detected; K-Kidney; L-Liver; M-Muscle

Table 3: Tabular representation of location wise distribution of Ceftiofur residues using HPLC.

\begin{tabular}{|c|c|c|c|c|c|}
\hline $\begin{array}{l}\text { Sl. } \\
\text { No. }\end{array}$ & Locations & $\begin{array}{l}\text { Samples } \\
\text { Screened }\end{array}$ & Residue detected & $\begin{array}{l}\text { Detected } \\
\text { percentage }(\boldsymbol{\%})\end{array}$ & $\begin{array}{c}\text { Residue above } \\
\text { MRL }\end{array}$ \\
\hline 1 & Guwahati & 50 & $4(\mathrm{~K}-1, \mathrm{~L}-1, \mathrm{M}-2)$ & 8.00 & ND \\
\hline 2 & Jorhat & 36 & $3(\mathrm{~K}-1, \mathrm{~L}-1, \mathrm{M}-1)$ & 8.33 & ND \\
\hline 3 & Nalbari & 47 & $2(\mathrm{~K}-0, \mathrm{~L}-1, \mathrm{M}-1)$ & 4.26 & ND \\
\hline 4 & Tezpur & 36 & $1(\mathrm{~K}-1, \mathrm{~L}-0, \mathrm{M}-0)$ & 2.78 & ND \\
\hline 5 & Nagoan & 51 & $2(\mathrm{~K}-1, \mathrm{~L}-0, \mathrm{M}-1)$ & 3.92 & ND \\
\hline 6 & Goalpara & 38 & $1(\mathrm{~K}-0, \mathrm{~L}-0, \mathrm{M}-1)$ & 2.63 & ND \\
\hline 7 & Morigoan & 42 & $1(\mathrm{~K}-1, \mathrm{~L}-0, \mathrm{M}-0)$ & 2.38 & ND \\
\hline & TOTAL & $\mathbf{3 0 0}$ & $\mathbf{1 4}(\mathrm{K}-\mathbf{5}, \mathbf{L}-\mathbf{3 , M}, \mathbf{M})$ & $\mathbf{4 . 6 7}$ & ND \\
\hline
\end{tabular}


Screening of Marketed Pork for Ceftiofur residues by HPLC and UV-Vis Spectrophotometer

Table 4: Tissue distribution of Ceftiofur residue in pork

\begin{tabular}{|c|c|c|c|c|c|}
\hline & \multicolumn{2}{|c|}{ Using HPLC } & \multicolumn{2}{|c|}{ Using UV-Vis Spectrophotometer } \\
\hline $\begin{array}{c}\text { Samples } \\
\text { collected }\end{array}$ & $\begin{array}{c}\text { Residue detected } \\
\left(\text { concn., } \boldsymbol{\mu g ~ g}^{-1}\right)\end{array}$ & $\begin{array}{c}\text { Residue } \\
\text { detected } \\
\text { above MRL }\end{array}$ & $\begin{array}{c}\text { Residue detected } \\
\left(\text { concn., } \boldsymbol{\mu g ~ g}^{-1}\right)\end{array}$ & $\begin{array}{c}\text { Residue } \\
\text { detected } \\
\text { above MRL }\end{array}$ \\
\hline Kidney & 100 & $5(0.020-2.540)$ & ND & $4(1.380-3.120)$ & ND \\
\hline Liver & 100 & $3(0.018-2.229)$ & ND & $3(1.570-2.350)$ & ND \\
\hline Muscle & 100 & $6(0.015-0.410)$ & ND & $3(0.085-0.450)$ & ND \\
\hline Total & $\mathbf{3 0 0}$ & $\mathbf{1 4}$ & ND & $\mathbf{1 0}$ & ND \\
\hline
\end{tabular}

\section{Conclusion}

300 nos. of representative pork samples were collected from different pork markets of Assam. Out of the tested samples, 14 nos. of the screened samples were detected to be positive for trace residues of Ceftiofur using HPLC while 10 nos. of same samples were detected for Ceftiofur residue using Spectrophotometer which were well below the MRL value. It can be concluded that HPLC method is more sensitive than spectrophotometric method in detection of Ceftiofur residues in pork.

\section{ACKNOWLEDGEMENT}

The authors acknowledge the help and assistance received from ICAR and Directorate of Research (Vety),AAU, Khanapara.

\section{References}

[1] H. N. Booth; Mc. Donald, E. L. John's Veterinary Pharmacology and Therapeutics, $\left(5^{\text {th }}\right.$ edition, section 14 , Kalyani publishers India,1993), 766-67.

[2] R.E Hornish and S. F. Katarski, Cephalosporins in Veterinary Medicine - Ceftiofur Use in Food Animals, Current Topics in Medicinal Chemistry, 2 (7),2002, 717- 731

[3] R. L. Althaus, M. P Molina, M. Rodriguez and N. Fernandez, Detection limits of beta-lactam antibiotics in ewe milk by penzym enzymatic test, Journal of Food Protection ,64(11). 2001,1844-1847.

[4] M. A Payne, B. S Wetzlich, J. R Edward, Brown, Gardner, S. C James and L. C. Arthur . Comparison of the use of regulatory assays and high-performance liquid chromatography for detection of residues of ceftiofur sodium metabolites in tissue specimens of culled dairy cattle. American Journal of Veterinary Research.,65(12),2004, 1730-1733.

[5] Anonymus, Report on Integrated Sample survey for estimation of production of Milk, Egg and Meat, Directorate of Animal Husbandry \& Veterinary Department, Govt. of Assam, 2008-09.

[6] H. Oka, H. Matsumoto and K. Uno, Improvement of chemical analysis of antibiotics. VIII. Application of prepacked C 18 cartridge for the analysis of tetracycline residues in animal liver. Journal of Chromatography, 325, 1985, 265-274

[7] V. Annapurna, G. Jyothi, C. Rambabu and B.B.V Sailaja, Spectrophotometric determination of ceftiofur hydrochloride using Nbromosuccinimide and p-dimethylaminobenzaldehyde. E Journal of Chemistry 6(3), 2009,763-769.

[8] M.G Beconi-Barker, R.E Hornish, T.J Vidmar, K.J. Dame and S.A Brown, Ceftiofur hydrochloride: plasma and tissue distribution in swine following intramuscular administration at various doses. Journal of Veterinary Pharmacology and Therapeutics, 19(3),1996, 192-199. 